DOI: $\square$ https://doi.org/10.15407/techned2020.01.058

\title{
DETERMINING THE RESERVE CAPACITY OF THERMAL AND HYDROELECTRIC POWER STATIONS FOR FREQUENCY AND POWER FLOWS REGULATION IN ISP OF UKRAINE
}

Journal

Publisher

ISSN

Issue

Pages
Tekhnichna elektrodynamika

Institute of Electrodynamics National Academy of Science of Ukraine 1607-7970 (print), 2218-1903 (online)

No 1, 2020 (January/February)

$58-63$

\section{Authors}

\section{O. Yandulskyi ${ }^{\star}$ A. Nesterko**, H. Trunina ${ }^{\star \star *}$}

National Technical University of Ukraine Igor Sikorsky Kyiv Polytechnic Institute, pr. Peremohy, 37, Kyiv, 03056, Ukraine,

e-mail: a_trunina@ukr.net

* ORCID ID : https://orcid.org/0000-0002-0362-7947

** ORCID ID : https://orcid.org/0000-0001-7488-4214

*** ORCID ID : https://orcid.org/0000-0002-4044-4955

\section{Abstract}

The problem of proper quality of primary and secondary frequency and power flows regulation in IPS of Ukraine is considered in the context of an increase in the share of renewable energy sources in the energy balance of the IPS of Ukraine. An approach and criteria have been developed for determining the optimum value from the technological point of view and the allocation of power reserves in the Ukrainian Interconnected Energy System on reconstructed and non-reconstructed units/aggregates of thermal power plants and hydroelectric power stations. Based on the results of IPS regimes simulation modeling in cases of sudden, likely by criterion $N-1$, imbalances of active power, a list and the need to attract non-reconstructed units/aggregates of power plants to primary and secondary load-frequency regulation is determined. References 10, table 1.

Key words: frequency regulation, active power reserves, primary and secondary frequency control, renewable energy sources, interconnected power system. 
Received: 01.07.2019

Accepted: 05.11.2019

Published: 16.01.2020

\section{References}

1. The development plan of the transmission system for $2020-2029$ years. Kyiv: NPC Ukrenerho, 2019. 208 p. (Ukr)

2. Report on conformity assessment (adequacy) of generating capacities. Kyiv: NPC Ukrenerho", 2018. 126 p. (Ukr)

3. Kyrylenko O., Pavlovsky V., Steliuk A. AGC software model validation for identification of renewables impact on frequency control in the IPS of Ukraine. 2014 IEEE International Conference on Intelligent Energy and Power Systems

(IEPS). Kyiv. 2014. Vol. 1. Pp. 141-144.

DOI:

https://doi.org/10.1109/IEPS.2014.6874166

4. Market rules. Kyiv: National Commission for State Regulation of Energy and Public Utilities, 2018. 178 p. (Ukr)

5. Method of determination of the size and allocation of active power reserves for frequency and power flows control. Basic technical requirements for parallel operating power systems of the CIS and Baltic countries. Rosiia: OAO CO EES, 2006. 9 p. (Rus)

6. Kilk K. Determination of optimal operating reserves in power systems. Oil Shale. 2009. Vol. 26. No 3. Pp. 220-227.

DOI:

https://doi.org/10.3176/oil.2009.3S.05

7. The rules for calculating the choice of the composition of generating equipment. Rosiia: NP Sovet rynka, 2015. 19 p. (Rus)

8. On approval of the Code of transmission systems: Resolution of the National Commission for State Regulation in the Fields of Energy and Public Utilities No 309 of 14.03.2018. (Ukr)

9. Methods and recommendations for the organization of primary and secondary frequency and power regulation at power units of the TPP. SOU-N EE 04.157: 2009 Kyiv: Minpalyvenerho Ukrainy, 2009. 56 p. (Ukr)

10. Yandulskyi O., Marchenko A., Hulyi V. Analysis of Efficiency Of Primary Load-Frequency Control of Integrated Power System of Ukraine. 2018 IEEE 3rd International Conference on Intelligent Energy and Power Systems

(IEPS).

Kharkiv. 2018. Pp. 244-247.

DOI:

https://doi.org/10.1109/IEPS.2018.8559567 
$\underline{\text { PDF }}$

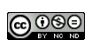

This work is licensed under a Creative Commons Attribution-NonCommercial-NoDerivatives $\underline{4.0 \text { International License }}$ 